\title{
Purification, Immobilization and Characterization of Lipase Isoenzyme from Aspergillus niger with C8 Magnetic Particles
}

\author{
Samanta Hernández-García*, María Inmaculada García-García, Francisco García-Carmona \\ Department of Biochemistry and Molecular Biology A, Faculty of Biology, Regional Campus of International \\ Excellence "Campus Mare Nostrum", University of Murcia, Campus Espinardo, Murcia, Spain \\ Email: samanta.hernandez@um.es
}

Received 30 April 2014; revised 30 May 2014; accepted 12 June 2014

Copyright @ 2014 by authors and Scientific Research Publishing Inc.

This work is licensed under the Creative Commons Attribution International License (CC BY). http://creativecommons.org/licenses/by/4.0/

c) (i) Open Access

\section{Abstract}

The purification of a lipase isoenzyme from an Aspergillus niger lipase $A$ is reported in this manuscript. Purification was carried out in a simple adsorption step, in which the lipase was offered at low ionic strength to the commercially available C8 modified magnetic particles, MaKProt C8. When the isoenzyme was desorbed with a $0.2 \%$ solution of Triton $X-100$, the SDS-PAGE gel showed a single pure band with a molecular weight of $35 \mathrm{KDa}$. The purified fraction showed 66.75-fold purification compared with the crude extract. The pure fraction was characterized along with the crude extract and the lipase adsorbed on the MaKProt $\mathrm{C8}$. The purified and the adsorbed lipase showed better activity for the tested substrates ( $p$-nitrophenyl acetate, decanoate, myristate and palmitate) than the crude extract, the preferred substrates being myristate $\left(26.7 \mu \mathrm{mol} \cdot \mathrm{min}^{-1} \cdot \mathrm{mg}^{-1}\right)$ and decanoate $\left(17.4 \mu \mathrm{mol} \cdot \mathrm{min}^{-1} \cdot \mathrm{mg}^{-1}\right)$, respectively. The temperature and $\mathrm{pH}$ profiles showed no change for the three enzymes, the optimum temperature being $37^{\circ} \mathrm{C}$ and the best $\mathrm{pH}$ 7.0.

\section{Keywords}

Protein Purification, Protein Affinity, Magnetic Hydrophobic Particles, Protein Immobilization, Lipase Purification, Lipase Isoenzyme, C8 Magnetic Particles

\section{Introduction}

Lipases (EC 3.1.1.3) are the most widely used enzymes in biotransformation since they offer a broad range of reactions that can catalyze: hydrolysis, aminohydrolysis, esterification, enantio and region selectivity [1]-[4].

${ }^{*}$ Corresponding author.

How to cite this paper: Hernández-García, S., García-García, M.I. and García-Carmona, F. (2014) Purification, Immobilization andCharacterization of Lipase Isoenzyme from Aspergillus niger with C8 Magnetic Particles. Advances in Bioscience and Biotechnology, 5, 633-641. http://dx.doi.org/10.4236/abb.2014.57075 
Lipases are produced by many microorganisms either alone or together with other members of the hydrolase family, like esterases. Among microorganisms, fungi are widely recognized as preferable lipase sources because they generally produce extracellular enzymes, which facilitate enzyme recovery from the fermentation broth. Aspergillus niger is one of the most important microorganisms used in biotechnology. It has already been in use for decades to produce many extracellular enzymes that are considered GRAS (Generally Regarded As Safe) by the FDA (Food and Drug Administration of the United States of America) [5].

The crude extracts obtained from the fermentation broth of Aspergillus niger contain many enzymes with lipase and esterase activities that have shown affinities for the target substrate [6]. The different properties of each enzyme in the mixture could be a problem for characterizing and optimizing the process, and, moreover, the results may change from batch to batch. It is, therefore necessary to develop an easy and fast process for lipase purification for processes in which pure enzymes are needed. The interfacial adsorption of lipases on hydrophobic supports has been proposed as a simple purification method, since lipases are well known for the ease with which they are adsorbed onto such supports [7].

Magnetic particles have a unique property that permits their quick and selective removal from almost any reaction medium, also can be modified with any of the ligands already used in chromatography (anionic, cationic, hydrophobic or affinity ligands), making them ideal for use in downstream protein purification processes. The development of magnetic particles for protein purification use has attracted a lot of attention in the last decade, e.g., the use of magnetic particles modified with iminodiacetic acid and charged with nickel for the selective purification of a histidine modified GFP as reported by Franzred et al. [8], and the work of Tong et al. [9] in which a purified lysozyme of hen egg-white is obtained through a purification process mediated with Cibacron Blue 3GA, also Holschuh et al. [10] reported the purification of Ig2b antibody from mouse with magnetic particles that had Protein A as a ligand.

In this work, a lipase isoenzyme was isolated from an Aspergillus niger crude extract using commercial magnetic particles functionalized with a C8 aliphatic chain, the MaKProt C8. Also, the characteristics of the lipase adsorbed onto the C8 support were tested, because when the lipases are adsorbed onto a hydrophobic interphase, their conformational structure changes due to strong interaction with the interphase, resulting in an activity increase associated with the change of conformation [11] [12]. The magnetic properties of the support permit a fast recovery from the medium without the need for centrifugation or filtration, minimizing the overall purification time.

\section{Materials and Methods}

\subsection{Materials}

Amano Lipase A from Aspergillus niger was purchased from Sigma Aldrich (Sigma-Aldrich Quimica SL Madrid, Spain). MaKProt C8 magnetic particles functionalized with hydrophobic aliphatic chain were purchased from MagBioteK (www.magbiotek.com). The lipase substrates and the rest of the reagents were also purchased from Sigma Aldrich. Protein marker Spectra ${ }^{\mathrm{TM}}$ Multicolor Broad range Protein ladder with a molecular weight between 260 - 10 KDa was purchased from Thermo Scientific (Thermo Fisher Scientific Inc., Spain).

\subsection{Methods}

\subsubsection{Lipase Purification}

Three grams of the MaKProt C8 magnetic particles were washed three times with phosphate buffer $(5 \mathrm{mM}, \mathrm{pH}$ 7.0), following the manufacturer's instructions. The support was sonicated for 10 minutes in $3 \mathrm{~mL}$ of the same buffer, and then $3 \mathrm{~mL}$ of lipase solution $(20 \mathrm{mg} / \mathrm{mL})$ were added. The mixture was incubated at $25^{\circ} \mathrm{C}$ for 1 hour. Then the particles were thoroughly washed with phosphate buffer $(5 \mathrm{mM}, \mathrm{pH} 7.0)$ ten times, and the lipase isoenzymes were desorbed with a $0.2 \%$ Triton X-100 solution in phosphate buffer ( $5 \mathrm{mM}, \mathrm{pH} 7.0)$ for $15 \mathrm{mi}-$ nutes $25^{\circ} \mathrm{C}$. All the experiments were made for triplicate and the errors were calculated as the typical deviation of the mean value.

\subsubsection{SDS-PAGE Analysis}

The desorbed samples were firstly concentrated with trichloroacetic acid: briefly, $100 \mu \mathrm{L}$ of the sample were mixed with $100 \mu \mathrm{L}$ of TCA (20\%) for 20 minutes in ice, before centrifuging at $13000 \times$ g; 10 minutes, the pel- 
lets were washed with ethanol and left to dry. The pellets were then resuspeded in $30 \mu \mathrm{L}$ of 0.125 Tris base containing $0.2 \%$ bromophenol blue, 10\% 2-Mercaptoethanol, 40\% Glycerol and 4\% SDS, and boiled for 15 minutes. Samples $(25 \mu \mathrm{L})$ were loaded onto a mini-PROTEAN electrophoretic unit (Bio-rad. Inc.) using gels with a $12 \%$ acrylamide separation zone and a stacking zone of $4 \%$ acrylamide. The gels were stained following the coomassie blue method.

\subsubsection{Densitometry Analysis}

The gel was scanned and submitted to densitometry analysis with Image Scanner II (Amersham science), using Image Quant TL (GE Healthcare Life Sciences) software.

\subsubsection{Lipase Immobilization}

The magnetic particles were also tested as immobilization support: $2 \mathrm{~mL}$ of lipase solution $(20 \mathrm{mg} / \mathrm{mL})$ in phosphate buffer (5 mM, pH 7.0) were mixed with 2 grams of MaKProt C8 magnetic particles (suspended in 2 mL phosphate buffer $5 \mathrm{mM}, \mathrm{pH}$ 7.0) and incubated at room temperature for 1 hour. Then the immobilized lipase was washed up to ten times with the same buffer and stored at $4^{\circ} \mathrm{C}$ in $4 \mathrm{~mL}$ of phosphate buffer (5 mM, pH 7.0) for further analysis.

\subsubsection{Protein Assay}

Protein concentration was estimated with the Bicinchoninic acid method [13]: in brief, the determination reagent was prepared adding $1 \mathrm{~mL}$ of Copper (II) Sulfate Pentahydrate 4\% Solution, (Sigma Product No. C2284) to 49 $\mathrm{mL}$ of bicinchoninic acid solution (Sigma Product No. B9643). Then $2 \mathrm{~mL}$ of this reagent was mixed with 0.1 $\mathrm{mL}$ of protein solution, and the tube was incubated for 30 minutes at $37^{\circ} \mathrm{C}$. Then, the tubes were left to cool and the adsorbance was determined at $562 \mathrm{~nm}$. BSA $(10 \mathrm{mg} / \mathrm{mL})$ was used as protein standard.

\subsubsection{Lipase Activity Assays}

The lipase, the immobilized lipase and the extracted fraction activities were tested against 4-nitrophenylcarboxylates of different aliphatic chain lengths, namely 4-nitrophenylacetate (C2), decanoate (C10), myristate (C14) and palmitate (C16) [14]. In a normal assay an enzyme sample was added to a $1 \mathrm{~mL}$ spectrophotometric cuvette containing $5 \mu \mathrm{L}$ of substrate $(1 \mathrm{mg} / \mathrm{mL}$ in acetone) and phosphate buffer (50 mM, pH 7.0). The release of 4-nitrophenol was measured at 400nm in a Shimazu spectrophotometer UV 2401 PC (SHIMAZU CORPORATION Japan) equipped with a temperature controller Shimazu TCC CONTROLER 24017. The Specific activity was defined as the micromoles of p-nitrophenol that a $1 \mathrm{mg}$ of enzyme releases in 1 minute. The optimum temperature was obtained in the range between $25^{\circ} \mathrm{C}$ and $50^{\circ} \mathrm{C}$, and the optimum $\mathrm{pH}$ between 5.0 and 9.0 , for the range 5.0 - $8.050 \mathrm{mM}$ phosphate buffer was used and for 8.0 - $9.050 \mathrm{mM}$ tris/ $\mathrm{HCl}$ was used. All the experiments were made for triplicate and the errors were calculated as the typical deviation of the mean value.

Other set of experiments were made to assure than the lipase did not leach from the support in aqueous medium, it was a normal assay where the adsorbed enzyme was attracted with a magnet then the supernatant was removed and refilled with fresh reaction medium, three cycles were made. The substrate was p-nitrophenyldecanoate $(5 \mu \mathrm{L})$ in phosphate buffer $\left(50 \mathrm{mM}\right.$ pH7) at $37^{\circ} \mathrm{C}$.

\section{Results and Discussion}

\subsection{Lipase A Purification}

Lipase A was adsorbed onto a C8 hydrophobic magnetic support. As can be seen Figure 1, more than the 85\% of the supplied lipase was adsorbed within one hour (the C8 support adsorbed pproximately17.7 mg of lipase per gram of support). Once the lipase was adsorbed on the support surface, the support was submitted to an exhaustive washing to remove the more hydrophilic isoenzymes, while maintaining the more hydrophobic ones.

Then a $0.2 \%$ Triton X-100 solution was used to extract the remaining fraction. As Figure 2 shows, the isolated fraction obtained was a single protein band with a molecular weight of around 35 KDa. There are few other reports of Aspergillus niger isoenzyme purification. For example Höfelmann et al. who characterized two lipases from a crude extract with a molecular weight of 31 and $19 \mathrm{KDa}$, respectively, using a three step purification method: DEAE-Trisacryl M ion exchange chromatography, Sephadex G 50 gel filtration and hydrophobic chromatography using Phenylsepharose CL-4B [15]. Namboodiri et al. that obtained an extracellular lipase from 


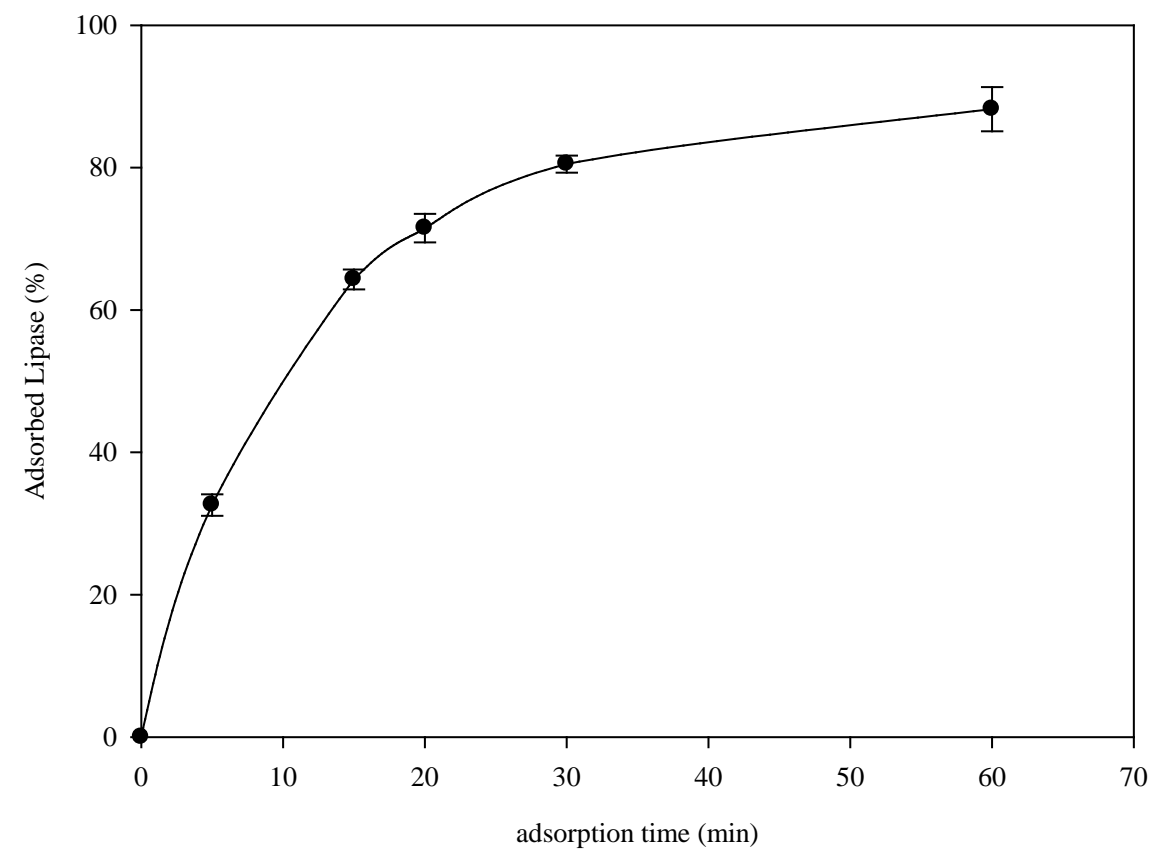

Figure 1. Lipase adsorption curve onto MaKProt C8 hydrophobic support, $60 \mathrm{mg}$ of lipase comercial extract was added to $3 \mathrm{~g}$ of MaKProt C8 magnetic particles, aliquots were withdraw at time intervals. The protein concentration in the supernatant was determined by the bicinchoninic acid method.

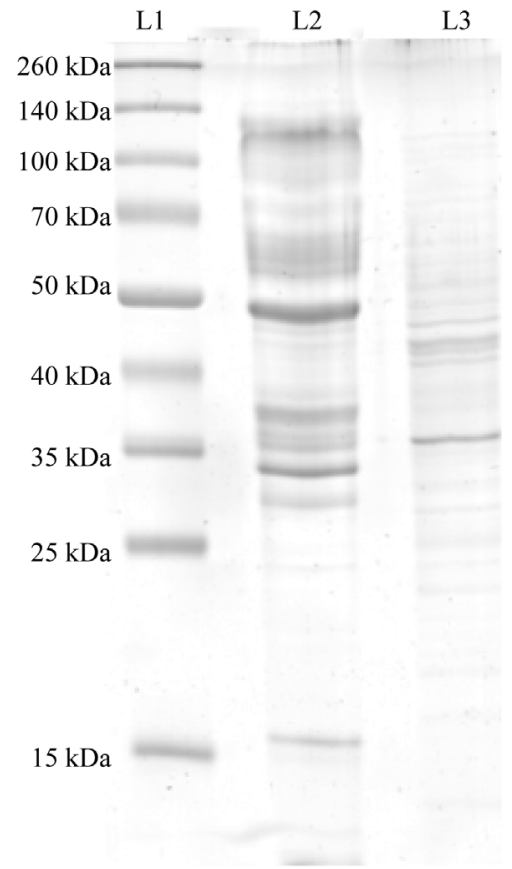

Figure 2. SDS PAGE of purified lipase A from Aspergillus niger. Lane 1 is the protein marker, Lane 2 lipase crude sample; Lane 3 purified extract from the MaKProt C8 magnetic particles.

Aspergillus niger with a molecular weight of $35.5 \mathrm{KDa}$ by $\mathrm{pH}$ precipitation followed by a series of chromatographic steps [16]. The Figure 2 was submitted to a densitometry analysis, and the analysis showed that the majority of the peaks of the crude extract had disappear in the purified extract leaving only a single well shaped 
peak.

As can be seen in the SDS gel the commercial extract from lipase is a mixture of enzymes with various molecular weights, which can be fast purified in one step with a hydrophobic support, such as MaKProt C8.The magnetic properties of the support make it fast to recover without filtration or centrifugations, and it only takes a few seconds to separate the particles from the solution by magnet. Table 1 shows the properties of the different fractions involved in the lipase A purification steps. As can be seen in the table, although most of the enzyme was adsorbed on the support a high amount was washed away in the washing step, probably because these isoenzymes were not hydrophobic enough and were removed within the washing buffer. Even with this loss of enzyme the extracted fraction showed more specific activity towards the p-nitrophenyl acetate than the commercial extract, reaching a 66.75-fold purification.

The mechanism proposed for the lipase purification is showed in Figure 3, as can be seen that the lipases with hydrophobic zones were adsorbed on the support leaving the hydrophilic ones in the supernatant. In the washing step the lipases that had weak hydrophobicity get washed away leaving only on the support the strong hydrophobic ones. The adsorbed lipases can be used within the support as immobilized on magnetic particles for reactions in aqueous mediums, or can be eluted with a Triton X-100 solution.

\subsection{Characterization of Lipase A, Extracted Lipase and Immobilized Lipase on C8 Magnetic Particles}

The crude lipase extract and the purified lipase, and also the isoenzyme immobilized onto the C8 particles used for the purification were characterized. Figure 4 shows the different substrate affinities of the free commercial extract from lipase, the extracted isoenzyme and the immobilized isoenzyme. As can be seen the extracted isoenzyme and the immobilized extract had much more specific activity towards the four substrates than the free one. The free enzyme showed more affinity for a more hydrophilic substrate such as p-nitrophenyl acetate than for the more hydrophobic substrates, the activity for the p-nitrophenyl palmitate, which has the longest aliphatic chain of all the tested compounds, being negligible.

The purified extract shows the highest specific activity of all those studied, its preferred substrate being the p-nitophenyl myristate. This increase in activity was due to the purification process and also to the surfactant used in the desorption step (Triton X-100), as it is well know that surfactants such as Triton, Tween or Brij act

Table 1. Purification of lipase A from Aspergillus niger.

\begin{tabular}{cccc} 
& Total protein $(\mathrm{mg})^{\mathrm{a}}$ & Yield (\%) & $\begin{array}{c}\text { Specific Activity } \\
\mu \mathrm{mol} / \mathrm{min}^{\mathrm{b}} / \mathrm{mg}^{\mathrm{b}}\end{array}$ \\
\hline Lipase & $59.3 \pm 2.1$ & $100 \pm 1$ & $0.4 \pm 0.05$ \\
C8 supernatant & $7.48 \pm 1.2$ & $21.33 \pm 3.2$ & $0.1 \pm 0.025$ \\
C8 Extract & $1.25 \pm 0.1$ & $59.25 \pm 2.8$ & $26.7 \pm 0.5$ \\
\hline
\end{tabular}

${ }^{\mathrm{a} B i c i n c h o n i n i c}$ acid method; ${ }^{\mathrm{b}} \mathrm{p}$-nitrophenyl myristate as substrate.

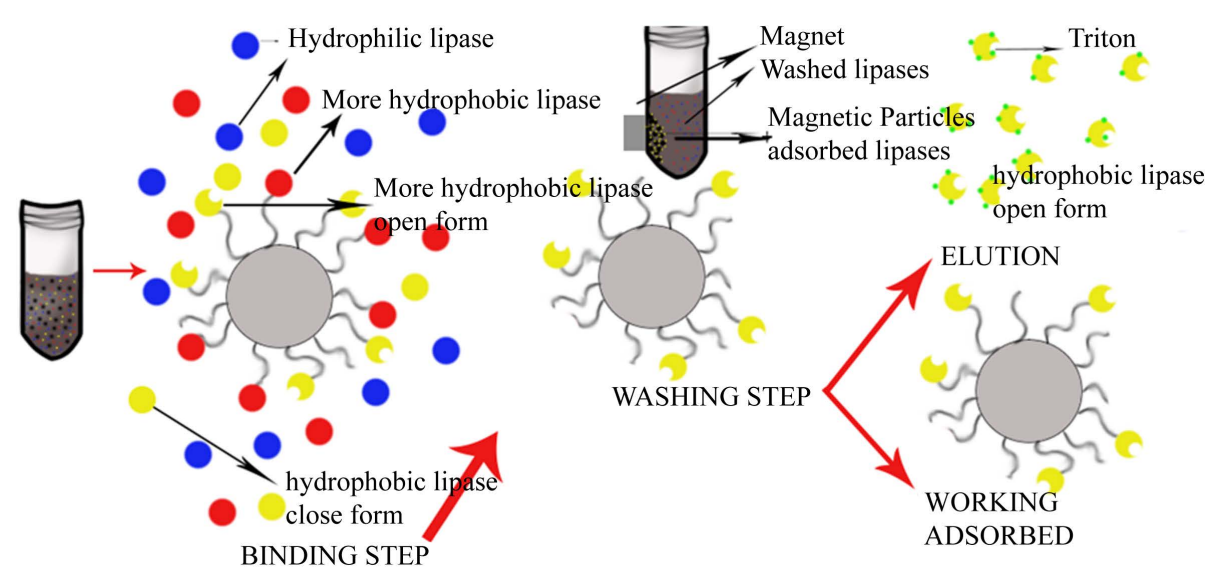

Figure 3. Proposed mechanism for the lipase purification with MaKProt C8 magnetic particles. 


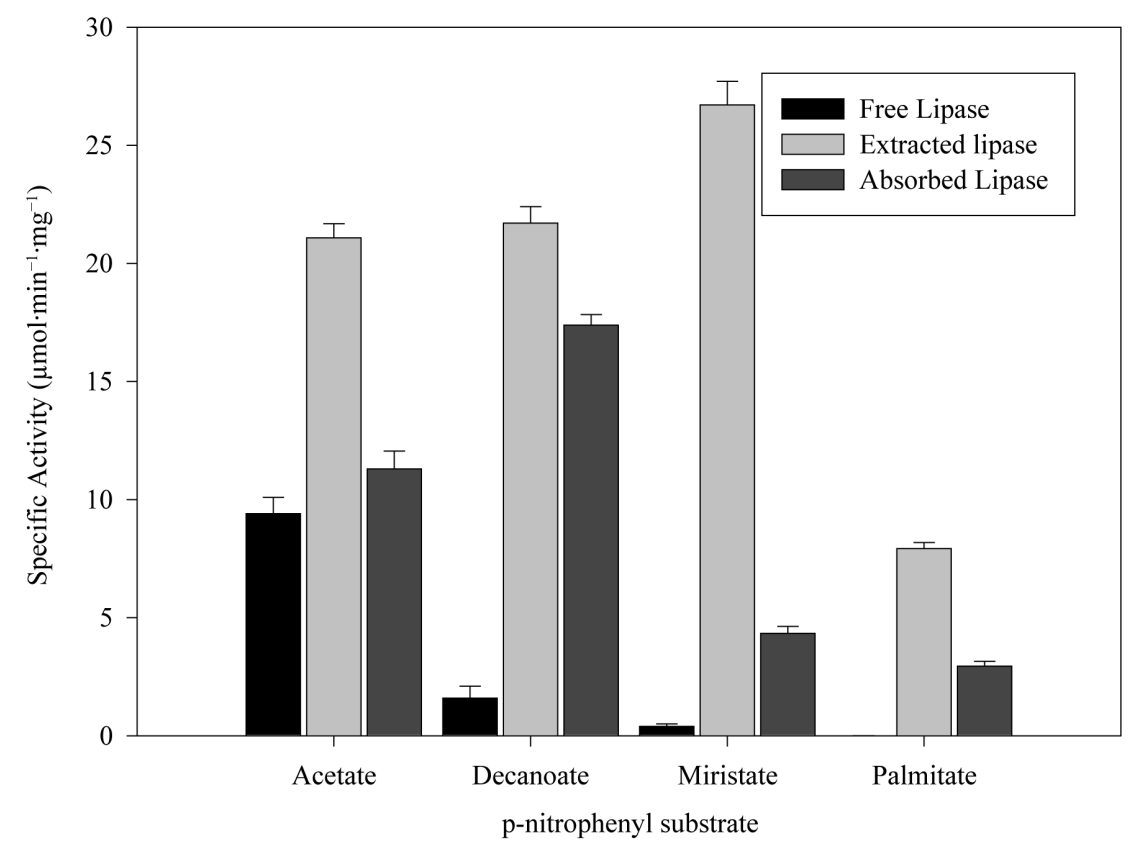

Figure 4. Free lipase, extracted lipase and adsorbed lipase specifity toward nitrophenyl substrates, the reaction medium contains $5 \mu \mathrm{L}$ of substrate, $50 \mu \mathrm{L}$ of enzyme and $945 \mu \mathrm{L}$ of phosphate buffer $50 \mathrm{mM} \mathrm{pH} 7$, at $25^{\circ} \mathrm{C}$.

as lipase activating compounds [17]-[20]. The p-nitropheny ldecanoate seems to be the preferred substrate for the immobilized enzyme, which is more hydrophobic than the p-nitrophenyl acetate with a longer aliphatic chain. The activity for the more hydrophobic substrates myristate and palmitate was lower but nerveless still higher than for the free enzyme. This higher activity for all the substrates shown by the immobilized enzyme could be due to the purification process that the lipase undergoes when adsorbed on the particles and its adsorption in a more active structural conformation. In comparison with Wang et al., who immobilized Candida rugosa lipase on handmade C8 particles, the lipase immobilized on MaKProt C8 magnetic particles showed more specific activity for p-nitrophenyl acetate. The immobilized lipase described by these authors had a specific activity of 1.5 $\mu \mathrm{mol} \cdot \mathrm{min}^{-1} \cdot \mathrm{mg}^{-1}$ [7], while our immobilized lipase showed $11.3 \mu \mathrm{mol} \cdot \mathrm{min}^{-1} \cdot \mathrm{mg}^{-1}$, an increase of activity that could be attributed to the particle size. The MaKProt C8 particles have a mean size of $300 \mathrm{~nm}$, as reported the manufacturer, while Wang et al. reported a mean size of $10 \mathrm{~nm}$. The bigger particle size of MaKProt C8 means a bigger gap between the end of the aliphatic chains, preventing enzyme clumping and steric hindrance. It also increased the availability of the substrate. Other set of experiments were made to assure that the lipase did not leach from the support in aqueous medium, the absorbed lipase was reused three times in p-nitrophenyl decanoate hydrolysis, the assays showed almost the same specific activity $45.2,46.7$ and $43.1 \mu \mathrm{mol} \cdot \mathrm{min}^{-1} \cdot \mathrm{mg}^{-1}$ respectively, meaning that in the assay conditions the lipase was strong attached to the hydrophobic support and did not tend to leach from it.

The temperature profiles of the free enzyme, the purified enzyme and the immobilized one could be seen in the Figure 5. As can be seen, all the profiles have a curved shape, the optimal temperature being around $37^{\circ} \mathrm{C}$ $40^{\circ} \mathrm{C}$ for the three enzymes, which agrees with the consulted bibliography [16] [21]. Of note is, the increase in activity between $25^{\circ} \mathrm{C}$ and the optimal temperature: the increase was $62.3 \%$ in the case of the extracted lipase for p-nitrophenyl myristate, the immobilized enzyme has a $65.4 \%$ activity increase for the p-nitrophenyl decanoate, and the free lipase has an increase $43.81 \%$ for the p-nitrophenyl acetate, this data shows how important the temperature profile is for an enzyme, such as lipase. The $\mathrm{pH}$ profiles for the three enzymes were also studied and are represented in Figure 6. The optimum $\mathrm{pH}$ for the enzymes was 7.0 which agrees with the literature [22].

\section{Conclusion}

This work describes the purification and characterization of a lipase from an Aspergillus niger commercial ex- 


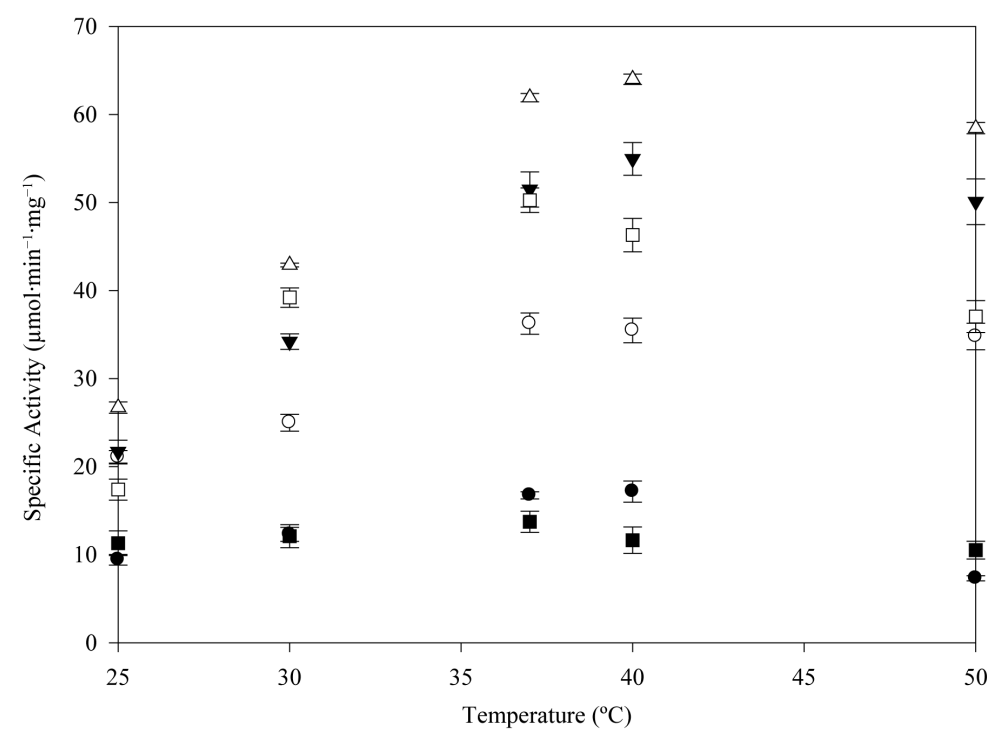

- $\quad \mathrm{T}\left({ }^{\circ} \mathrm{C}\right)$ vs Free lipase acetate

○ $\quad \mathrm{T}\left({ }^{\circ} \mathrm{C}\right)$ vs Extracted lipase acetate

$\checkmark \quad \mathrm{T}\left({ }^{\circ} \mathrm{C}\right)$ vs Extracted lipase decanoate

$\triangle \quad \mathrm{T}\left({ }^{\circ} \mathrm{C}\right)$ vs Extracted lipase miristate

- $\quad \mathrm{T}\left({ }^{\circ} \mathrm{C}\right)$ vs Immobilized lipase acetate

$\square \quad \mathrm{T}\left({ }^{\circ} \mathrm{C}\right)$ vs Immobilized lipase decanoate

Figure 5. Temperature profiles for the crude enzyme extract, the purified isoenzyme and the immobilized enzyme. The reaction medium contains $5 \mu \mathrm{L}$ of substrate, $50 \mu \mathrm{L}$ of enzyme and $945 \mu \mathrm{L}$ of phosphate buffer $50 \mathrm{mM} \mathrm{pH} \mathrm{7,} \mathrm{at} \mathrm{different} \mathrm{temperatures.}$

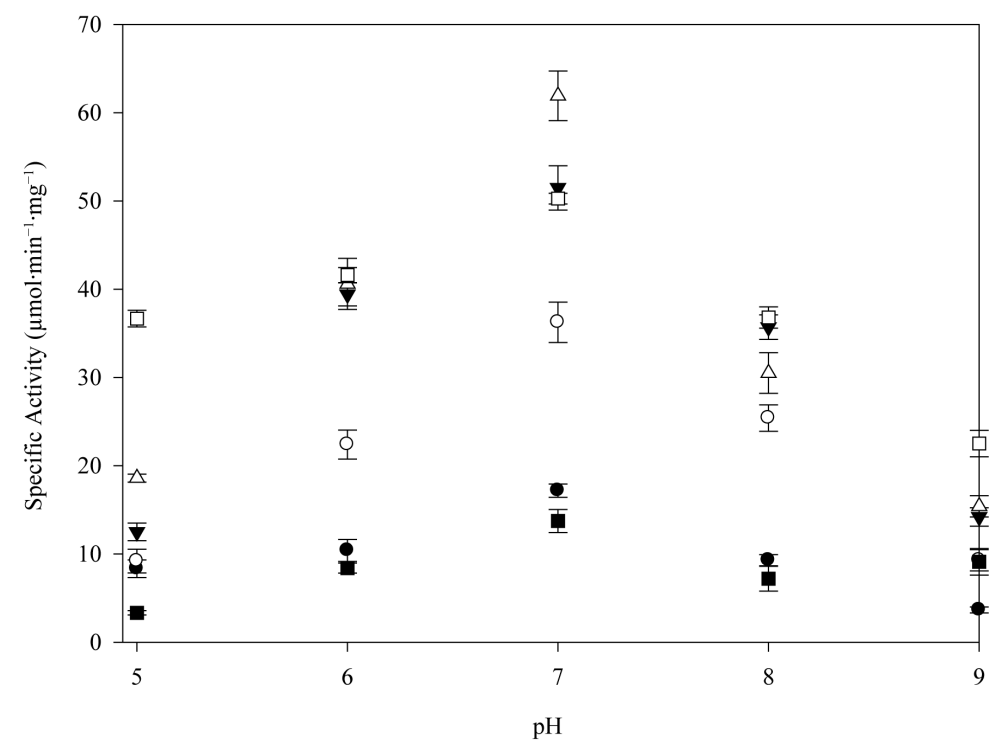

$$
\begin{array}{ll}
\text { - } & \mathrm{pH} \text { vs Free enzyme acetate } \\
\circ & \mathrm{pH} \text { vs Extracted enzyme acetate } \\
\nabla & \mathrm{pH} \text { vs Extracted enzyme decanoate } \\
\triangle & \mathrm{pH} \text { vs Extracted enzyme miristate } \\
\square & \mathrm{pH} \text { vs Immobilized enzyme acetate } \\
\square & \mathrm{pH} \text { vs Immobilized enzyme decanoate }
\end{array}
$$

Figure 6. pH profiles for the free lipase, the purified lipase and the immobilized onto $\mathrm{C} 8$ particles. The reaction medium contains $5 \mu \mathrm{L}$ of substrate, $50 \mu \mathrm{L}$ of enzyme and $945 \mu \mathrm{L}$ of buffer phosphate $50 \mathrm{mM} \mathrm{pH}(5.0-8.0)$ or $50 \mathrm{mM}$ Tris/ $\mathrm{HCl}(8.0-9.0)$, at $37^{\circ} \mathrm{C}$. 
tract using the commercially available MaKProt C8 magnetic particles modified with hydrophobic aliphatic chains, in a fast and easy one-step purification method. The magnetic properties of the particles facilitate supernatant removal and the washing steps, as it takes less than a minute for the particles to be attracted by a magnet, reducing considerably the purification time. The obtained lipase, with a molecular weight of 35KDa, is 66.75fold that was more pure than the crude extract source, and had better specific activity for all the tested substrates than the crude extract. The preferred substrate was p-nitrophenyl myristate while the preferred substrate for the free enzyme was p-nitrophenyl acetate. Additionally, the lipase adsorbed onto the MaKProt C8 magnetic particles, was characterized. The immobilized enzyme showed more affinity for the substrate p-nitrophenyl decanoate and more specific activity for the four tested substrates than the crude extract, indicating the interfacial activation that the lipases undergo when adsorbed onto hydrophobic surfaces.

\section{Acknowledgements}

This work was supported by Ministerio de Ciencia y Innovación (MICINN, FEDER, Spain) (Project AGL201125023) and by Programa de Ayuda a Grupos de Excelencia de la Región de Murcia, Fundación Séneca, Agencia de Ciencia y Tecnología de la Región de Murcia (Plan Regional de Ciencia y Tecnología 2007-2010). S. H-G. is the holder of a predoctoral research grant, associated with the above project from Fundación Séneca.

\section{References}

[1] Jaeger, K.E. and Reetz, M.T. (2000) Directed Evolution of Enantioselective Enzymes for Organic Chemistry. Current Opinion in Chemical Biology, 4, 68-73. http://dx.doi.org/10.1016/S1367-5931(99)00054-X

[2] Koeller, K.M. and Wong, C.H. (2001) Enzymes for Chemical Synthesis. Nature, 409, 232-240. http://dx.doi.org/10.1038/35051706

[3] Virto, M.D., Lascaray, J.M., Solozabal, R. and de Renobales, M. (1991) Enzymic Hydrolysis of Animal Fats in Organic Solvents at Temperatures below Their Melting Points. Journal of the American Oil Chemists Society, 68, 324-327. http://dx.doi.org/10.1007/BF02657686

[4] Chen, Y.Z., Yang, C.T., Ching, C.B. and Xu, R. (2008) Immobilization of Lipases on Hydrophobilized Zirconia Nanoparticles: Highly Enantioselective and Reusable Biocatalysts. Langmuir, 24, 8877-8884. http://dx.doi.org/10.1021/la801384c

[5] Pera, L.M., Romero, C.M., Baigori, M.D. and Castro, G.R. (2006) Catalytic Properties of Lipase Extracts from Aspergillus niger. Food Technology \& Biotechnology, 44, 247-252.

[6] Palomo, J.M., Fernández-Lorente, G., Mateo, C., Fernández-Lafuente, R. and Guisan, J.M. (2002) Enzymatic Resolution of ( \pm )-trans-4-(4'-Fluorophenyl)-6-Oxo-Piperidin-3-Ethyl Carboxylate, an Intermediate in the Synthesis of (-)Paroxetine. Tetrahedron: Asymmetry, 13, 2375-2381. http://dx.doi.org/10.1016/S0957-4166(02)00645-6

[7] Wang, J., Meng, G., Tao, K., Feng, M., Zhao, X., Li, Z. and Lu, J.R. (2012) Immobilization of Lipases on Alkyl Silane Modified Magnetic Nanoparticles: Effect of Alkyl chain Length on Enzyme Activity. PloS one, 7, e43478. http://dx.doi.org/10.1371/journal.pone.0043478

[8] Franzreb, M., Ebner, N. and Siemann-Herzberg, M. (2003) Magnettechnologie in der Bioproduktaufreinigung. Transkript, 9, 112-115.

[9] Tong, X.D., Xue, B. and Sun, Y. (2001) A Novel Magnetic Affinity Support for Protein Adsorption and Purification. Biotechnology Progress, 17, 134-139. http://dx.doi.org/10.1021/bp000134g

[10] Holschuh, K. and Schwämmle, A. (2005) Preparative Purification of Antibodies with Protein A-An Alternative to Conventional Chromatography. Journal of Magnetism and Magnetic Materials, 293, 345-348. http://dx.doi.org/10.1016/j.jmmm.2005.02.050

[11] Van Tilbeurgh, H., Egloff, M.P., Martinez, C., Rugani, N., Verger, R. and Cambillau, C. (1993) Interfacial Activation of the Lipase-Procolipase Complex by Mixed Micelles Revealed by X-Ray Crystallography. Nature, 362, 814-820. http://dx.doi.org/10.1038/362814a0

[12] Brady, L., Brzozowski, A.M., Derewenda, Z.S., Dodson, E., Dodson, G., Tolley, S. and Menge, U. (1990) A Serine Protease Triad Forms the Catalytic Centre of a Triacylglycerol Lipase. Nature, 343, 767-770. http://dx.doi.org/10.1038/343767a0

[13] Smith, P.K., Krohn, R.I., Hermanson, G.T., Mallia, A.K., Gartner, F.H., Provenzano, M. and Klenk, D.C. (1985) Measurement of Protein Using Bicinchoninic Acid. Analytical biochemistry, 150, 76-85. http://dx.doi.org/10.1016/0003-2697(85)90442-7

[14] Gupta, R., Rathi, P., Gupta, N. and Bradoo, S. (2003) Lipase Assays for Conventional and Molecular Screening: An 
Overview. Biotechnology and Applied Biochemistry, 37, 63-71. http://dx.doi.org/10.1042/BA20020059

[15] Höfelmann, M., Hartmann, J., Zink, A. and Schreier, P. (1985) Isolation, Purification, and Characterization of Lipase Isoenzymes from a Technical Aspergillus niger Enzyme. Journal of Food Science, 50, 1721-1725. http://dx.doi.org/10.1111/j.1365-2621.1985.tb10574.x

[16] Namboodiri, V.M.H. and Chattopadhyaya, R. (2000) Purification and Biochemical Characterization of a Novel Thermostable Lipase from Aspergillus niger. Lipids, 35, 495-502. http://dx.doi.org/10.1007/s11745-000-549-3

[17] Chang, S.W., Lee, G.C. and Shaw, J.F. (2006) Efficient Production of Active Recombinant Candida Rugosa LIP3 Lipase in Pichiapastoris and Biochemical Characterization of the Purified Enzyme. Journal of Agricultural and Food Chemistry, 54, 5831-5838. http://dx.doi.org/10.1021/jf060835e

[18] Shangguan, J.J., Liu, Y.Q., Wang, F.J., Zhao, J., Fan, L.Q., Li, S.X. and Xu, J.H. (2011) Expression and Characterization of a Novel Lipase from Aspergillus fumigatus with High Specific Activity. Applied Biochemistry and Biotechnology, 165, 949-962. http://dx.doi.org/10.1007/s12010-011-9311-2

[19] Karadzic, I., Masui, A., Zivkovic, L.I. and Fujiwara, N. (2006) Purification and Characterization of an Alkaline Lipase from Pseudomonas aeruginosa Isolated from Putrid Mineral Cutting Oil as Component of Metalworking Fluid. Journal of Bioscience and Bioengineering, 102, 82-89. http://dx.doi.org/10.1263/jbb.102.82

[20] Quyen, D.T., Giang Le, T.T., Nguyen, T.T., Oh, T.K. and Lee, J.K. (2005) High-Level Heterologous Expression and Properties of a Novel Lipase from Ralstonia sp. M1. Protein Expression and Purification, 39, 97-106. http://dx.doi.org/10.1016/j.pep.2004.10.001

[21] Van Heerden, E., Litthauer, D. and Verger, R. (2002) Biochemical Characterisation and Kinetic Properties of a Purified Lipase from Aspergillus niger in Bulk Phase and Monomolecular Films. Enzyme and Microbial Technology, 30, 902-909. http://dx.doi.org/10.1016/S0141-0229(02)00031-5

[22] Romero, C.M., Baigori, M.D. and Pera, L.M. (2007) Catalytic Properties of Mycelium-Bound Lipases from Aspergillus niger MYA 135. Applied Microbiology and Biotechnology, 76, 861-866. http://dx.doi.org/10.1007/s00253-007-1067-9 
Scientific Research Publishing (SCIRP) is one of the largest Open Access journal publishers. It is currently publishing more than 200 open access, online, peer-reviewed journals covering a wide range of academic disciplines. SCIRP serves the worldwide academic communities and contributes to the progress and application of science with its publication.

Other selected journals from SCIRP are listed as below. Submit your manuscript to us via either submit@scirp.org or Online Submission Portal.
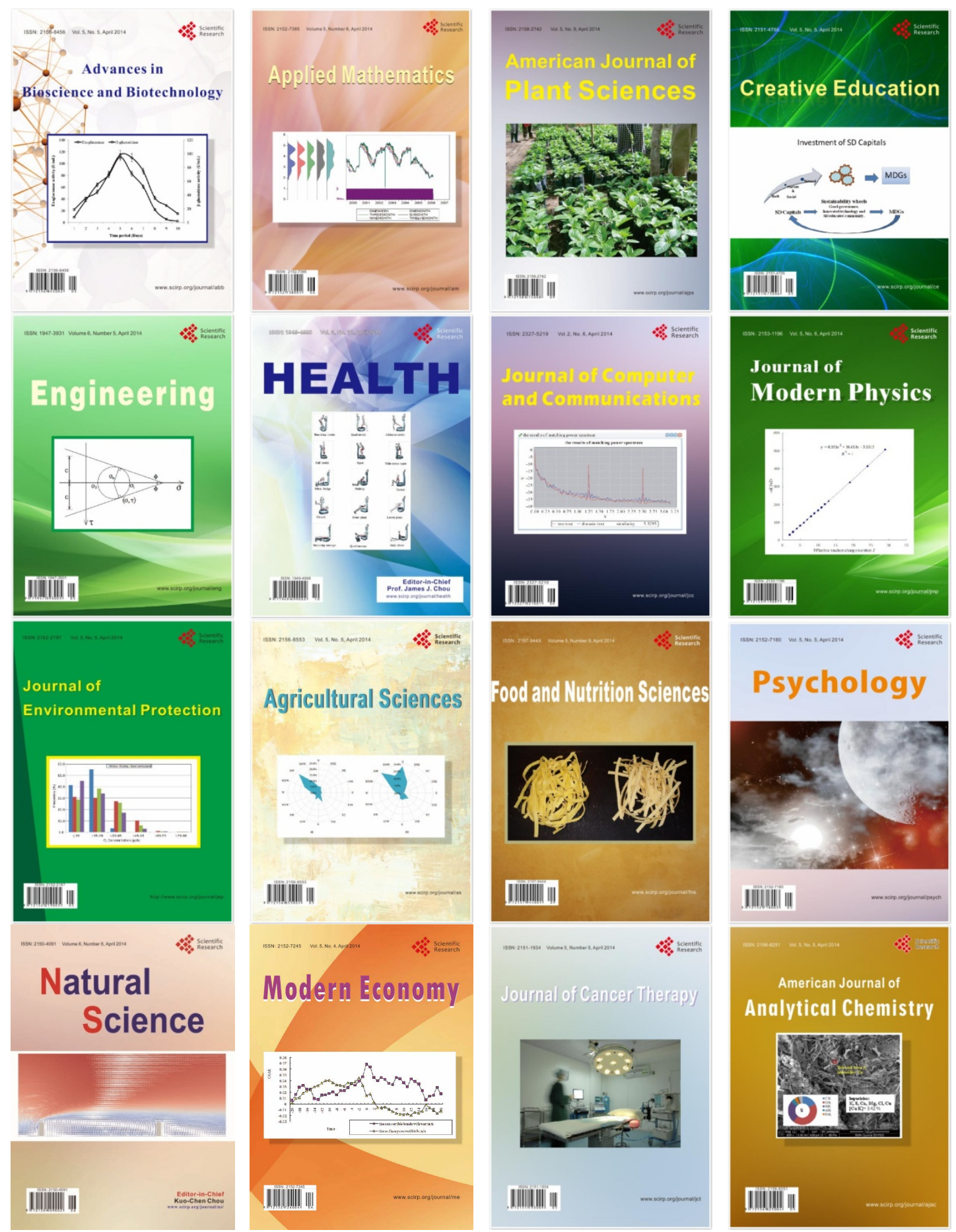